\title{
The spoken (he)art of strategy - A metaphor analysis of the strategy discourse of 10 South African business executives
}

\author{
J. Foster-Pedley*, D. Bond and R. Brown \\ Graduate School of Business, University of Cape Town, \\ Private Bag, Rondebosch 7701, Republic of South Africa \\ jon@fosterpedley.com
}

Received November 2004

\begin{abstract}
This paper investigates the importance of metaphor in strategy in several ways. Firstly it considers the problematic nature of 'strategy' itself. Next, it outlines some views on how metaphor is used in strategy discourse, with particular emphasis on innovation, emergent processes and sense-making. It is then proposed that not only is metaphor useful in describing or making sense of strategy, but it is also central to 'doing' strategy - that strategy is, in important ways, metaphoric.
\end{abstract}

This paper explores the proposition that research methods based on metaphor analysis can provide fundamental and useful insights into how business strategy is performed and understood. It also raises questions about the way strategy is taught. A description follows providing the results of research carried out on ten senior business executives in South Africa. A number of conclusions are derived from this research:

(i) metaphor, which is useful in communicating ideas and meanings, appears to emerge as required to emphasize, construct new meaning and persuade rather than as a tool to support any particular dominant interest

(ii) metaphor opens up paradoxical space

(iii) metaphor is fundamental in articulating strategy

(iv) speakers were generally not aware of their use of metaphor, in spite of a frequent richness of metaphor use

(v) when the speakers were made aware of their use of metaphor, they were less able to engage in further discussion using metaphor and

(vi) when ceasing to use metaphor, they seemed less able to engage in discussion and thought about strategy.

Finally, some questions are raised from a more 'critical' perspective. The critical analysis in our paper tests a synthesis of the analytical frameworks of Lakoff and Johnson (1980) and Fairclough (1989;1992b) to see what can be 'surfaced' through this type of metaphor analysis, and consider what implications there may be for management education.

Ultimately, the heart of strategy may lie in the art of sense-making and creativity via discourse and conversation. Part of this spoken art lives in and by metaphor, which lightens and eases the paths to new understandings, new directions and to new configurations of individuals, firms and markets.

*To whom all correspondence should be addressed.

\section{Introduction}

\section{The problematic nature of strategy.}

Strategy is hard to define and when defined is frequently done so amidst contention (Shrivastava, 1986; Ansoff, 1991; Whittington, 1993; Porter 1996). What the word 'strategy' signifies, its 'field' and its purpose have evolved to the point where '... (the field itself) has become a highly contested and questioned site, one riddled with competing models' (Barry \& Elmes, 1997). There seems to be an increasing discussion that focuses on the ontologies underlying the debate (Aldrich, 1992; Barney, 1994) - that strategy, like time, can be what you make it. Mintzberg, Ahlstrand and Lampel (1998) present ten schools of strategy, some prescriptive, others descriptive as a basis for understanding the field. Strategy seems beset by paradox and contradiction. It must be, variously, planned and emergent, formed and formulated, made into or made out of (Mintzberg, 1987 \& 1994; Mintzberg \& Quinn, 1991; Hampden-Turner, 1990). Strategy tends to be described in an organised and rational manner, yet frequently appears to be enacted in extra-ordinary ways. Thus there seems a clear divergence between the ways in which strategy is presented and the ways in which it is performed (Stacey, 1996). This can lead to some elaborate sense-making procedures and rationalizing when attempts are made to describe or communicate strategy (Weick, 1994). These sense-making maneuvers, which appear strained to a point of cerebral gymnastics on occasion, seem to be trying to make a link between a belief-system that holds that strategy is rationallyordered and can be described as such, and an experience base that informs the actor that strategy is anything but sensible (Pascale, 1989; Knights \& Morgan, 1990; Barley \& 
Kunda, 1992). Yet in spite of this obvious dissonance, the tools and techniques of strategy generally remain obdurately rational - or rather, the tools and techniques generally focus on creating rational presentation, on presenting order and system from the confusion of action and on proposing that rational approaches will be useful. As a result, much of what is seen to be strategic learning is presented in rational or intellectual terms, and the focus of teaching of strategy still seems to be largely on the analytical, rather than on the synthesizing and integrative processes in strategy (, Ahlstrand \& Lampel, 1998). Indeed recent works resolutely challenge the fabric, purpose and process of MBA teaching (Mintzberg, 2004). Is this the best way forward? If strategy is acted out in a creative, adaptive and coping manner, albeit supported by analysis, do the current tools of analysis provide much value? (Hamel \& Prahalad, 1995). Is there a better way of understanding what 'strategy' is and how it comes to be?

It is possible to explore the classifications applied to strategy at length. Most frequently they seem to share two characteristics. The first one is time-lines, i.e. a description of a 'progression of theory' that unfolds over time as a knowledge advances through research and practice (Gouillart, 1995). Typically a progression from a Taylorian machine metaphor towards an organic metaphor is presented. This is linked to a second classification in which environmental or contextual turbulence forces an adaptation in theory or a change in framing which is presented as paradigm-breaking - generally the results of factors such as globalisation, technology, changing nature of business towards knowledge-based models etc. Amongst the paradigm-breaking classifications one can find a range of fascinating debates: modern/post-modern, chaos and complexity, game theory. Yet even in these debates it seems hard to escape from an underlying mode of argument which is dualistic and which seems to represent a mythic and timeless conflict between old and new, in which the enlightened grapple with the forces of darkness, ignorance (and of accountants - the supposed villains of denominator, rather than numerator, management) (Ritzer, 1993; De Cock, 1996; Hamel \& Prahalad, 1995).

There are, of course, many other ways of presenting strategy. For example Prahalad and Bettis (1986) present diagnostic depth as a useful framework whereby the level at which a strategy decision or intervention is made is related to that at which a medical condition can be 'cured'. See Table 1.

\section{Table 1: Diagnostic depth}

\begin{tabular}{|c|c|c|}
\hline Level & Medical diagnosis & Strategy equivalent \\
\hline 1 & $\begin{array}{l}\text { - } \text { Headache, take aspirin. } \\
\text { - } \quad \text { Patient 'cured', but.. } \\
\text { - } \quad \text { see doctor, doctor refers to specialist }\end{array}$ & $\begin{array}{l}\text { - Low profits. Cut costs. Profitability returns. Company } \\
\text { 'cured', but.... } \\
\text { - refer to consultant }\end{array}$ \\
\hline 2 & $\begin{array}{l}\text { - Specialist prescribes quadruple bypass } \\
\text { - } \quad \text { Patient 'cured', but.. }\end{array}$ & $\begin{array}{l}\text { - Consultant conducts industry analysis and finds underlying } \\
\text { industry problem. Advises reengineering and diversification } \\
\text { - Company 'cured', but.... }\end{array}$ \\
\hline 3 & $\begin{array}{l}\text { - Specialist looks at life style - prescribes no } \\
\text { smoking, exercise, reduce alcohol. Patient } \\
\text { 'cured' (disease prevented/delayed) }\end{array}$ & $\begin{array}{l}\text { - Consultant explores why company couldn't have discovered } \\
\text { problems for itself - finds managerial 'thinking lifestyle' } \\
\text { problems - recommends new recruitment, training, etc. } \\
\text { Company 'cured' }\end{array}$ \\
\hline 4 & $\begin{array}{l}\text { - Specialist investigates family and finds history } \\
\text { of heart disease } \\
\text { - Genetic factors (at present) are hard to cure }\end{array}$ & $\begin{array}{l}\text { - Genetic equivalent is managerial beliefs - whether based on } \\
\text { the organisation's way of seeing things, or the national } \\
\text { culture's, or an individual's or society's set of beliefs of } \\
\text { ontologies (e.g. primacy of scientific rationalism etc.) } \\
\text { 'Dominant Logic' }\end{array}$ \\
\hline
\end{tabular}

Derived from Prahalad and Bettis (1986).

This table illustrates the different levels at which problems can be diagnosed and provides an analogy between medicine and organizational strategy. Actions at higher levels of 1 and 2 are frequently presented as strategy - e.g. downsizing, changing industry type, business process reengineering, etc. Yet it is arguable that these actions are less strategic and even 'easier' than actions at lower levels of 3 and 4. Paradoxically though, these level 3 and 4 factors may be represented as less serious change management or HR issues. At higher levels results are more tangible, measurable, causality easier to attribute, responsibility for results easier to claim and actions more immediate. At lower levels actions have more leverage, are harder to measure, results somewhat vaguer and more ambiguous to describe and impact less easy to chart. Working at these lower levels equates to focusing on organisational wellness rather than on working at higher levels where actions focus on symptoms of underlying pathologies.

Whilst Prahalad and Bettis (1986) focus on depth, Whittington (1993) is concerned with scope. In order to provide order to the theories, he proposes a category based on two axes:

Axis 1: Deliberate (belief that strategy can be manipulated, is plastic, and that cause-effect relationships exist) vs. Emergent (strategy is messy and patterns emerge, sense has to be dug out or looked for, rationality is bounded).

Axis 2: Single outcome (normally profit or its equivalent measure) vs. Multiple outcomes (political solutions, ideological compromises, informed guessing from 
inherently limited data, etc). This provides four categories of strategy into which he attempts to place theories: Classical (single/deliberate), Processual (multiple/ emergent), Evolutionary (single/emergent) and Systemic (multiple/deliberate). Foster-Pedley finds more use for this framework as a teaching device at MBA level (training wheels, to give balance in negotiating a complex field) than as a basis for academic research, where its limitations become quickly apparent as the matrix represents overly forced choices.

Both models consider the implicit beliefs concerning the role of human agency and the different strategy processes that may follow from, for example, differing beliefs concerning cognition in collectivist or individualistic cultures (Lessem \& Neubauer, 1994; Markus \& Kitiyama, 1991).

Another view could be constructed according to a model of dynamism, vitality or immediacy. For example, there is recurrent theme along the lines of: 'theory is to strategy as religion is to spirituality' (Hamel \& Prahalad, 1995) as follows in Table 2 (and one could surely construct a much more elaborate model).

\section{Table 2: Strategic dynamism}

\begin{tabular}{l|l|l}
\hline \multicolumn{1}{c|}{ Strategy } & \multicolumn{1}{c}{ Strategy? } & \multicolumn{1}{c}{ Authors } \\
\hline Religion & Spirituality & Hamel \& Prahalad (1995) \\
\hline Noun & Verb & Whittington (1996) \\
\hline Sense made & Sense making & Stacey (1996); Pascale (1990) \\
\hline Plans and reports & Narrative \& storytelling & Barry \& Elmes (1997); Downing (1998); Boje (2001) \\
\hline
\end{tabular}

This view has some interesting connotations: is strategy presented differently when it is in the past than it is in the doing? Is strategy presented in literal and generalized ways so as to make it accessible to all in the organisation, i.e. to avoid alignment with any of the political groups that negotiated in its making - or in making its story? Is the objective and generalized language often used in textbooks, reports and in cases actually helpful in learning about strategy and learning to perform it? Is, indeed, past strategy talked about in literal language and current and future strategy talked about in figurative, metaphorical language? The difference between sense made and sense making is certainly worthy of attention in the attempt to access the moments of realization, insight and pattern-seeing that form part of strategy-as-present rather than strategy-as-past. Using the metaphor of the balanced scorecard, this is comparable to understanding the difference between lagging measures and leading measures in designing and fulfilling the strategy process itself.

\section{Metaphor in strategy discourse.}

Metaphor is defined online in dictionary.com (2004) as:

1. A figure of speech in which a word or phrase that ordinarily designates one thing is used to designate another, thus making an implicit comparison, as in 'a sea of troubles' or 'All the world's a stage'.

2. One thing conceived as representing another; a symbol: 'Hollywood has always been an irresistible, prefabricated metaphor for the crass, the materialistic, the shallow, and the craven'.

Webster's online dictionary (2004) contains some comments relevant to this article:

'Many consider metaphor to be at the heart of poetry (or even to define in part what it means to be human): the figure of speech that links dissimilar objects or concepts, establishing a non-deductive relationship. It is a way of expressing an idea, through an implicit paradox, that cannot be conveyed literally. In this sense, it is not only at the heart of poetry, but of science as well: ideas that are fundamentally original and new, can only be conveyed in this manner. Computers, and animals, do not and cannot use metaphor to communicate'.

Hill and Levenhagen (1995) state 'Metaphors are incomplete statements of one thing - in terms of another. If examined closely, metaphors express a logical inconsistency, incongruence or a contradiction'.

Putnam, Phillips and Chapman (1996), comment on the use of metaphor to uncover the complex ways in which 'communication' and 'organisation' are interrelated - 'One of the ways to unpack these complexities is to probe into the metaphors of organisational communication that represent research domains in the field... in particular... on the subtle features of metaphor clusters that reveal diverse representations...' It is a similar consideration that has driven this research: that the links between communication and organisation are hidden structures that determine the meanings and agreed actions that constitute strategy - yet these links are opaque to most of the tools or methods which have been agreed as belonging to the field of strategy in the past.

In rational narratives of strategy, effort is made to explain all the events and processes enacted. Nonetheless much remains unknown or inaccessible - essentially mysterious. Baudrillard (1997) says: 'Something must remain about what you do without you knowing what it is. Because things always come from somewhere else'. Metaphor seems to allow access to the unaccessed and unarticulated.

The literature on metaphor in strategy is developing (Barney, 1994; Palmer \& Dunford, 1996; Lissack, 1997). If 
metaphor is the medium of creative, conceptual thought - if it is the scaffold on which meaning is created and transferred (Lakoff \& Johnson, 1980; Veale, 1995) - then the fundamental proposition in this paper is that metaphor must hold a primary place in strategy, which by its nature seeks new, unique competitive advantages or configurations (Porter, 1996). Indeed, since Morgan's seminal works (1983, 1986) much has been written about the various types of metaphor that can be used to illustrate or reframe strategies. But relatively little research has been carried out on the role of metaphor itself in strategy, as distinct from an analysis of how strategy would look if seen through the lens of a particular metaphor - e.g. strategy is war, or sport (Morgan, 1986; Hunt \& Menon, 1995; Barry \& Elmes, 1997). If our proposition is valid, then actors can be expected to use metaphors extensively in communicating about strategy. Furthermore, this use of metaphor may be unconscious and if it were, then this would be a further confirmation of the essential nature of metaphor to strategic thought (Nonaka, 1991).

For example - if the idea that 'strategy is narrative' is considered, then the role of metaphor raises several layers of questions - firstly, what is the role of metaphors used as part of the narrative? Secondly, what is revealed about strategy by framing it as the metaphor of narrative? And thirdly, why is it that metaphor seems to offer so many insights into strategy? Are these insights derived from academic interpretations or do practitioners find it useful to work in metaphor? Do they, in fact, have to work in/via metaphor to 'do' strategy, whether they are conscious of it or not?

The intellectual space to study and include metaphor in strategy has been, happily, opening up. Sanchez (1997) proposes that complexity concepts are expanding the field to move from 'context' to 'process' variables, from industry to cognitive processes, from commitment to flexibility, from control systems to self-management systems. Stacey (1996) has widened the field by using complexity metaphors such as complex adaptive systems, shadow organisations and fitness landscapes, by discussing the dynamics of revolution inherent in over stable system, by highlighting the effects of emotion, aspiration, inspiration and anxiety and by proposing variables for research such as agent variety, power differential, information flows, etc. He goes further to suggest reasons for the use of metaphor in strategic discourse, making the point that understanding of organizational dynamics is better achieved by understanding the shadow system of organisations. This shadow system is both spontaneously self-organising and lies outside the control of the formal or legitimate systems. He states that managers in this domain must use reasoning by analogy to understand vague yet powerful processes in the shadow system: 'The dynamics of the successful organisation are therefore those of irregular cycles and discontinuous trends, falling within qualitative patterns, fuzzy but recognisable categories taking the form of archetypes and templates....' and '......we have endless individual variety within broad categories - ... templates or archetypes. ... we would have to rely... on using qualitative patterns to reason by analogy and intuition. Those who succeeded in the borders between stability and instability would be those who saw patterns where others searched for specific links between causes and events.'

Hill (1998) has constructed a model of metaphor use in strategy that draws on complexity concepts of Stacey (1996), contending forces ideas of Pascale (1990), and group process theory by Bion (1961).

This framework serves to focus attention on various views of strategy, at different levels, and provides a basis from which to study the effects of metaphor.

1. The cognitive views of strategy concern sensemaking, creative thinking, and knowledge generation. Metaphors may assist, clarify and generate these processes (Nonaka 1994, Weick, in Hill \& Levenhagen, 1995) at various levels.

2. Behavioural explanations concern directing actions to achieve goals and metaphors may play a role in influencing behaviours and in capturing 'temporal tension' between a vision and current reality (Hill \& Levenhagen, 1995),

3. Affective explanations focus on the softer aspect of strategy - metaphors may provide greater affective contact than formal models. Foster-Pedley has had interesting and successful results in starting strategy programmes with an hour-long session on 'If strategy were an animal, what would it be?' The remarkable projections ascribed to variously, chameleons, dolphins, ants, elephants, eagles, jackals, and dung beetles ('rolls up the dung and gives it direction') reveal a living and vivid understanding of strategy that taps tacit knowledge in a way that surprises participants and is more real to them than descriptions of plans or planning processes.

Metaphors in strategic discourse have a number of characteristics, including the following; they:

- Exist in coherent systems

Metaphors may be used systematically, whether consciously or not, to elaborate a continuous line of thought or conceptual view, or to illustrate a forming pattern of analogy that enables the speaker to articulate emerging understandings. These can frequently exist in elaborate and coherent systems of metaphors

- Hide and reveal

By highlighting similarities between the one domain and another, they de-emphasise non-similar attributes

- Allow movement into the novel by reference to something already known

They create a scaffolding process (Vygotsky, 1962; 1978) allowing partial understandings of the novel to become more substantially known via reference to the familiar

- Allow play, and the unusual positioning of 'contradictory' ideas

By permitting play, they participate in the forming of the novel, and as such may signal the moments in the 
strategy process when new patterns of understanding are emerging

- Are how pre-verbal thought is formed

Not only do they participate in the pre-verbal and tacit domains, they may be a primary mechanism by which thought is formed, in the process of idea creation leading ultimately to articulation. As a result metaphors may be of significant interest to strategy researchers and practitioners since they are researchable elements of the sense-making process, rather than artefacts in the literal, sense-made world.
- Can be used to provide meaning and reduce anxiety Strategic planning routines may be better seen as social defences against the anxiety of knowing that much of what managers do may lie outside their control, especially those matters that are beyond the short-term (Stacey, 2002). Similarly metaphors may have the effect of reducing the anxiety of working with novelty by creating bridges of meaning between novel outcomes or directions and known, more comfortable concepts and experiences.

\section{Metaphor use framework}

\section{Environment}

\author{
Ambiguity, \\ paradoxes and \\ dilemmas
}

Environment

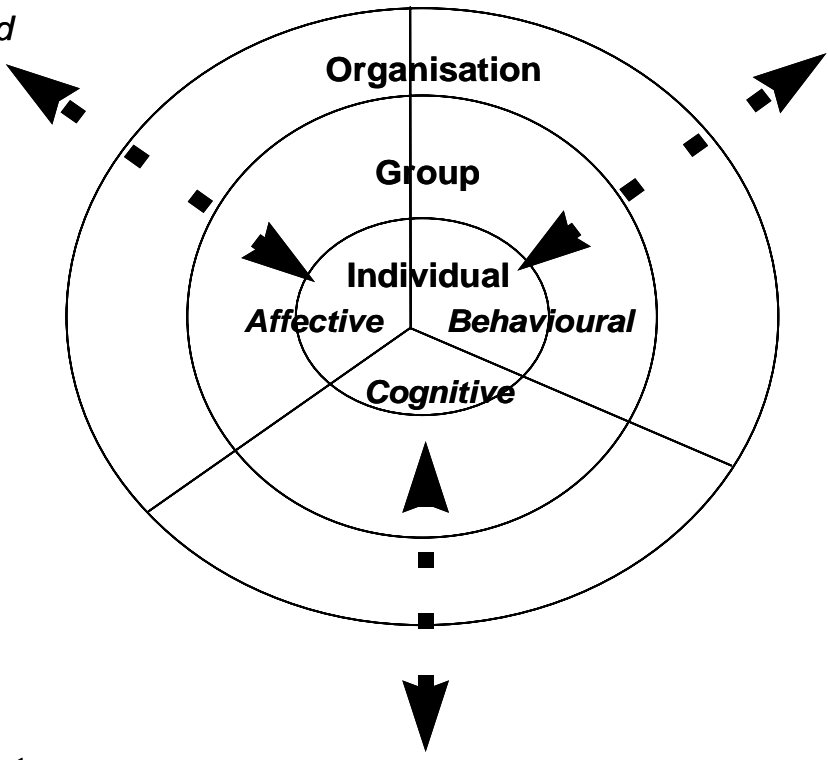

Ambiguity, paradoxes and dilemmas

\section{Environment}

Ambiguity, paradoxes and dilemmas

\section{Figure 1: Metaphor use framework}

Figure 2 illustrates three ideas. The first idea is an adaptation of concepts (Stacey, 1996) of 'zones' of strategy on a continuum between rigid inflexibility to meaningless chaos, with an area of strategic invention lying in between. The second idea presents some of the characteristic activities in each of these zones, varying from denial, to creative use of metaphor, to psychotic fantasy. The third idea suggests the zone in which creative intervention is possible for strategy practitioners and consultants. This we could call the zone of strategic in(ter)vention. Overall, this model presents metaphor as a typical activity of creative strategic thought. Furthermore as metaphor use is observable, it is also researchable so offering possibilities of gaining a better understanding of some the dynamics within this creative zone.

Other theory that relates to this work is that of Boje (2001) concerning story, narrative and antenarrative. Boje defines antenarrative as the 'fragmented, non-linear, incoherent, collective, and unplotted, and improper storytelling.......story is 'ante' to narrative; it is 'antenarrative'. A 'narrative' is something that is narrated, i.e. 'story'. Story is an account of incidents or events, but narrative comes after and adds 'plot' and 'coherence' to the story line. ......... Used as an adverb, 'ante' combined with 'narrative' or 'antenarrative' means earlier than narrative.' He adds: 'Narrative requires plot, as well as coherence. To narrative theory, story is folksy, without emplotment, a simple telling of chronology. I propose 'antenarrative'. To traditional narrative methods antenarrative is an improper storytelling, a wager that a proper narrative can be constituted. Narrative tries to stand as elite, to be above story'.

In these terms the research presented here can also be seen as investigating strategy as antenarrative, and as a contrast with the 'grand narrative' of classical strategy theory and models. It considers strategy meaning - or plot - being created under conditions when there is not sufficient 'preunderstanding or coherence to grasp together a plot' (Boje, 2001). The research seeks to answer whether metaphor analysis can reveal the spoken heart and art of strategy. 


\section{Strategic invention} zone

\section{Disintegration}

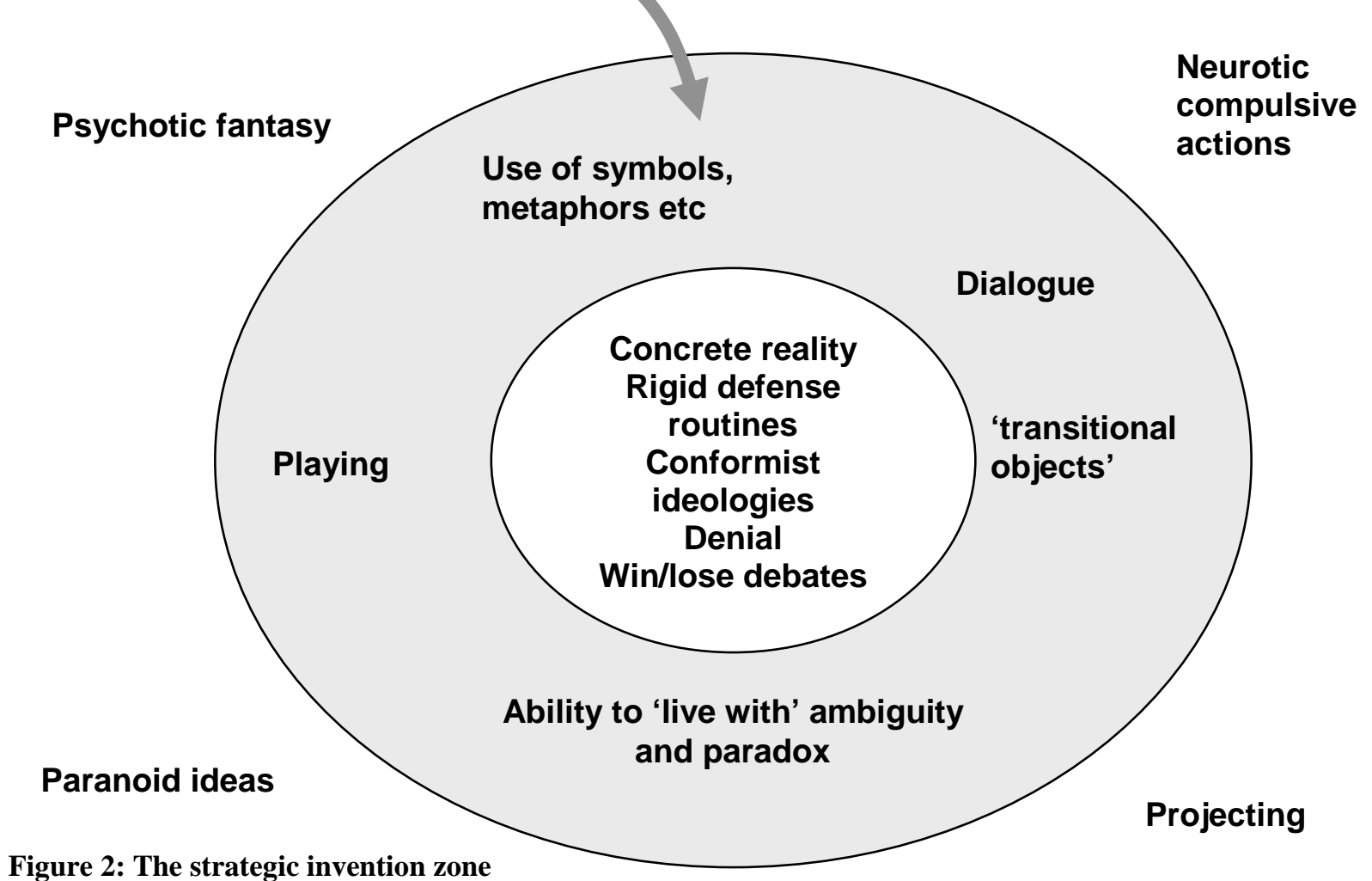

\section{The research.}

This paper describes the results of research into how the use of metaphorical analysis of interviews can provide fundamental and useful insights into how business strategy is performed and understood. It was decided to develop a method of metaphor analysis, drawing from a coherent range of research and analytical perspectives (Alvessen, 1993). Various methodologies have been presented for strategic analysis. (Pepper, 1942; Lakoff \& Johnson, 1980; Palmer \& Dunford, 1996). All of these offered significant insights. However for the purposes of this research, there was no single method that covered the requirements of an exploratory, broad investigation into the use of metaphor. A grounded approach was taken because of the theorybuilding, sense-making nature of the research. Stone's (1978) iterative approach of preparation, induction, deduction and prediction, verification and feedback fitted the need to develop ideas as the research unfolded.

Several roles of metaphor were considered for the purposes of the research:
a) providing a simple classification
b) maintaining consistency and stability
c) broadening understanding
d) understanding action
e) prediction (in the sense of creating shared sets of expectation that therefore guide action - self-fulfilling prophecies)
f) overcoming inaction
g) learning
h) handling ambiguity and paradoxes
i) combining reason and imagination
j) institutionalisation of preferred action
k) finding commonality

These roles were used as 'informing precepts' that guided the analysis of data.

Three hypotheses provided direction for the research, but they should more accurately be called propositions. They were:

\section{Proposition 1:}

Metaphor is fundamental to the articulation of strategy

\section{Proposition 2:}

Coherent systems of metaphorical use can be found in the articulation of strategy

\section{Proposition 3:}

Metaphor is used 'sporadically' (i.e. not in a consciously systematic manner) rather than as a tool to support any dominant mental schema. This is because metaphors are pervasively, tacitly, useful in talking about strategy, rather than consciously-chosen tools.

A number of drawbacks of metaphor were considered, including those presented by Palmer and Dunford (1996), Veale (1995) and Barry and Elmes (1997). These include the possibilities of too broad or multiple metaphor use 
leading to a highly divergent meaning that reduces clarity and the effect of metaphor to hide and much as it reveals. Further comments concerned the anxieties that can be provoked when interviewees find their own metaphors inadequate (dissonance) and that unchallenged use of metaphor can create 'skilled incompetence' in people who defend their preferred model through defensive routines (Argyris, 1985).

Interviews were carried out with 10 senior executives in South African firms and organisations. Men and women, they were selected to represent both public and private sector organisations and as being 'active strategists' by virtue of being in senior positions in organisations that attracted press comment or enjoyed peer repute - or as individuals meeting the same criteria. The method chosen was to conduct interviews, as described later, using open questions about strategy. There was no explicit signaling of the focus on metaphor until the end of the interview process. The interviews were taped and transcribed and during the interviews hand-written notes were also kept on contextual items, tenor, issues that might affect the interviews and other relevant observations of the interviewer.

The interview transcripts were analysed for metaphor drawing mainly on Lakoff and Johnson's (1980) analytical frameworks. The most effective questioning method was open, and non-intrusive, which created a space for relaxed thought.

The questions asked were:

1. What is strategy?

2. Does strategy matter to business and if so, why?

3. Hoe do you think of strategy?

4. Complete the sentence: 'Strategy is like....'

5. How do you assess strategy?

6. How is strategy altered?

7. What makes strategy successful?

8. Describe your business strategy in general terms.

9. What is the role of management and staff in strategy?

10. How does one go about doing strategy?

11. What imagery do you associate with strategy?

12. Does strategy evolve or is it a linear process?

The findings generally supported the propositions and indicated a number of further avenues for research. A broad summary of the findings shows that:

1. Metaphor use was rich - each interviewee called upon a wide variety of metaphors and diverse images.

2. Metaphor use was high-intensity, i.e. metaphor was consistently used in answering most questions. (The question of intent remained somewhat less clear, i.e. was metaphor used by design to answer most questions or less consciously in answering most questions? Further research might be useful here but the following point (3) seems to support the less deliberate approach to metaphor use).

3. Interviewees generally did not realise they used metaphor - at the end of the interviews when the purpose of the research was revealed, most interviewees apologised for using so little metaphor and claimed that they were not creative and did not think in images. The transcripts showed otherwise.

4. No one used a consistent, dominant, metaphor. Instead they tended to use a variety of different themes and even those who used the same theme indicated differences in interpretation.

5. Removing metaphor from the transcripts would have left little to analyze. Metaphor was crucial to articulating strategy for the interviewees.

Some further, tentative, observations were drawn from the interviews that open some intriguing avenues for research:

1. Using metaphor is a subconscious process - it appeared that using metaphor is a natural, subconscious process that is done effortlessly

2. When conscious of the use of metaphor, the process becomes more challenging - there were two question that most interviewees found hardest to answer were: Complete the sentence: 'Strategy is like....' and 'What imagery do you associate with strategy?'

3. Metaphors, once used, were built on and revisited later this may indicate a process of internalisation

4. Metaphors used early on in the interview made more sense (at least to the interviewer) later in the interviews when underlying, core metaphors were used

5. Metaphors were used to add fluidity, i.e. they were used to change the directions of arguments and to make leaps from simple to complex. Multiple metaphors were often used to facilitate flow of ideas

6. Metaphors were used, apparently without conscious thought, to add weight , persuasive effect and emotion to arguments

7. Metaphor use increased the farther the interview moved from specifics, or familiarity.

The question of whether coherent themes could be found was answered. Some interviewees returned to a theme over 20 times - one 48 times. In general themes were revisited 6 - 10 times. Nor was there any evidence of themes being exclusive - they were mixed and interwoven without apparent concern - getting the point across is what mattered. Different metaphors were used to describe different concepts - complexity might be consistently understood in terms of one metaphor and linear causality in terms of another. As interviewees used a metaphor it was readily extended to highlight further aspects of the issue or concept to which it referred.

There were a number of useful lessons for interview technique. Interviewees were generally uncomfortable at first with the abstract nature of the interviews. To paraphrase Lakoff and Johnson (1980) 'The fear of 
metaphor and rhetoric in the empiricist tradition is the fear of subjectivism - a fear of emotion and imagination'. But later during the interviews imagination was able to flow via metaphor. It was very noticeable that interjections in the interview process, e.g. requests for clarity affected the process. It created defensiveness and a search for logical coherence - a different discourse and a different exposition of 'strategy'. Open questions, a self-effacing interviewer and developed listening skills helped to create a constructive monologue.

A (partial) list of the explicit and implicit metaphors used by the interviewees, for the most part unconsciously, is reflected in Table 3:

This is deliberately uncategorised. Clearly each metaphor could be analysed individually to reveal its hidden assumptions and meanings about strategy - but this research was not concerned with this type of analysis. Instead it was concerned with whether the nature of strategy is generally misrepresented and perhaps misunderstood in many texts and particularly concerned whether the teaching of strategy is missing the point. Why emphasise literalism and positivism if the reality of strategy - many of the real 'valueadding' processes - is found in a quite different process that is accessed much more readily and expressed more vividly through metaphor? Perhaps the stimulation of creative thinking in teaching would be more valuable - if that is, the purpose of management education is to improve management and develop the capacity to think anew and not be simply a 'taking in of each other's dirty laundry' amongst academics (Williams, 1995).

The main conclusions of the research/data analysis were:

(i) metaphor, because of its usefulness, appears to emerge sporadically rather than as a tool to support dominant interest

(ii) metaphor opens up paradoxical space

(iii) metaphor is fundamental in articulating strategy

(iv) speakers were generally not aware of their use of metaphor, in spite of their frequent and rich use of metaphor

(v) when the speakers were made aware of their use of metaphor, they were markedly less able to engage in further discussion using metaphor and

(vi) when ceasing to use metaphor, they seemed less able to engage in discussion and thought about strategy.

Table 3: List of metaphors by interviewees

\begin{tabular}{l|l|l}
\hline \multicolumn{1}{c|}{ An iterative circle } & \multicolumn{1}{c}{ Nature } & \multicolumn{1}{c}{ Living thing } \\
\hline Forest/trees & Survival of a living thing & An animal \\
\hline A dynamo & Chess & Whiteboard \\
\hline Stagnation/death & Milestones & Stepping stones \\
\hline Rudder & Railway track & Safety net \\
\hline Casino & Lottery & Crystal ball gazing \\
\hline Moulding & Dreams & Negotiations \\
\hline Visions & Building a prototype & War \\
\hline Wargames & Growing crops & Driving a car \\
\hline Journey on foot & Maintaining a car & Military intelligence \\
\hline Way of being found & Reading a map & \\
\hline
\end{tabular}

The original propositions are generally supported by the research:

Proposition 1: Metaphor is fundamental to the articulation of strategy

This proposition was strongly supported. All interviewees spoke extensively in metaphors about strategy, in an apparently unselfconscious manner - especially at moments where ideas became more complex, where new ideas were emerging and where directional turns in conversation were taken.. That the removal of metaphors from the transcripts left little to analyse in them highlights the importance of metaphor for articulating ideas of strategy. Idea flow, conceptual and verbal fluency appeared linked to or facilitated by the use of metaphor in conversation about strategy.

Our view is that this finding is important to the way strategy can be approached both in education and in organisational practice. Research opportunities seem to exist in order to investigate ways to improve and enrich the teaching and learning of strategy.

Proposition 2: Coherent systems of metaphorical use can be found in the articulation of strategy.

This proposition was supported by the findings. Some interviewees extended their metaphors to elaborate their ideas in a systematic way. The evidence here was less conclusive than that supporting proposition 1 in that results were less general, but seems to offer directions for more research.

Proposition 3: Metaphor is used 'sporadically' (i.e. not in a consciously systematic manner) rather than as a tool to support any dominant mental schema. This is because metaphors are pervasively and tacitly useful in talking about strategy, rather than consciously-chosen tools. 
The evidence generally seems to support this proposition. The 'sporadic' or less-planned use of metaphor was more frequent and although systems or families of metaphors emerged, the actual use of metaphor was more spontaneous than planned.

In terms of research into enriching the teaching of strategy, Foster-Pedley is currently trialing different learning methods on MBA and executive programmes with interesting results. Participants have created board games and simulations, written allegorical fables and narratives, created their own theories and formulae of strategy, developed extended metaphors and are engaging in action research of their own strategy processes both in public and private sector organisations. It is expected that the results of this work will be presented for publication in 2005.

\section{Postscript: critical perspectives on strategic metaphor}

In the final section of this paper, we would like to raise some questions from a more 'critical' perspective. Reynolds (1997) identifies three characteristics of a critical perspective: questioning assumptions, analysing power relations, and focusing more on collective than individual issues.

It is precisely these kinds of issues and relationships which Fairclough seeks to investigate in his framework of critical discourse analysis (CDA). Fairclough has devised an analytical framework which integrates linguistic theory with discourse and social theory. One of his main concerns is to identify the ways in which language functions to maintain existing power relations in society. The reverse side of this concern is that he seeks to use his analysis to highlight signals of social change and challenges to conventional power relations. It is not our purpose here to give a detailed discussion of Fairclough's work. (For more detailed discussions of this model as well as examples of its application, see Fairclough, 1989, 1992a, 1992b, 1995; Fairclough \& Hardy, 1997; Janks, 1996; 1997). Rather, it is to provide brief examples of how the application of Fairclough's model points to a critical metaphor analysis which could add an interesting layer to the kind of analysis of strategy discourse discussed earlier in this paper.

In brief, Fairclough identifies three interrelated dimensions of discourse and discourse analysis:

1. Socio-cultural practice: the conditions of text production and interpretation - requiring social analysis.

2. Discourse practice: the process of production and interpretation - requiring processing analysis or interpretation.

3. The text (oral or written) - requiring text analysis.

Hilary Janks has done considerable work in applying Fairclough's model of analysis and in teaching its use to other researchers. The following is a summary of questions which could be applied to this strategy discourse, adapted from Janks’ guidelines to students (1988; 1997).
Socio-cultural practice: conditions of production and reception

1. What is the socio-historical context of the interviews?

2. What power relations: social, institutional, and situational shaped the strategy discourse recorded for analysis?

3. What are the common sense assumptions that underlie the strategy discourse recorded? What is taken for granted (by interviewer and interviewee)? What is presented as natural?

4. How is this strategy discourse positioned or positioning in relation to reproducing or changing social practice? Does it work to sustain or transform existing power relations?

The research was conducted by a student as part of the requirements for his MBA degree, in South Africa, three years after a considerable political transition in the country. What made him choose metaphor in strategy discourse as a focus at this particular time? To what extent did he assume or seek to identify if the strategy discourse in organizations may be reflecting the democratic thrust of the South African socio-political environment? Why did he choose the particular interviewees he did? What were his assumptions about who may be interesting respondents for discussions of business strategy? Did the choice of interviewees seem to perpetuate or challenge existing power relations in South African organizations in any way?

Discourse practice: processes of production and processes of reception

1. Who is speaking to whom (the interviews) writing for whom (the research report)? When? Where? On what occasion?

2. What relations exist between the speaker/writer and the listener/hearer?

3. What is going on (content)? Who is involved (subjects)? What relations exist between them (relations)? What is language - in this case, particularly metaphor - doing (connections)? What is the discourse type?

4. Who is the ideal listener/ reader of this text? How do the assumptions about what the reader/listener knows and values enable us to work out who the ideal reader is? What do intertextual references tell us about the ideal reader?

Who is talking to whom? What were the assumptions about what could and couldn't be discussed between and senior executive and an MBA student? An important feature here is that although all respondents were senior members of their organizations, the types of organizations differed considerably. Some were from businesses, others from nonprofit or trade union organizations. How did this influence the discourse of the interview? Did the head of a non-profit 
organization use similar metaphors and assumptions to counterparts in either business or trade unions, for example? To what extent did aspects of the democratic principles of trade unions permeate the discourse, particularly the metaphors of the trade union 'executive' - and are there indications of how coherent the discourse was with internal relations and practices? These differences at this particular time in South Africa's history, offered some rich material for exploration.

\section{Text analysis}

For text analysis, Fairclough's model would include metaphor as only one of a wide range of linguistic phenomena to explore. Here we are focusing particularly on metaphorical language. How is metaphor used to construct a representation of the world?

1. How do the metaphors work to position the listener/reader? Do they all pull in the same direction? Is there a pattern?

2. How does the overall construction of the text - logical reasoning, sequencing, visual selection and organisation, interaction patterns - contribute to this representation?

\section{Are there internal contradictions?}

Here again, the assumptions about the nature of strategy and about who gets to talk about strategy underpin the discourse as a whole. Lakoff and Johnson (1981:319ff.) note that metaphorical perspectives are (a) partial, and (b) do not reflect the only possible perspectives on the phenomena related through metaphor. That is, metaphorical utterances highlight some features associated with the topic discussed, but hide other features. The diversity of opinions and metaphors arising within the research interviews makes this point obvious. Nevertheless, the research has focused on and categorised what has been highlighted in each of the metaphors identified rather than what has been hidden. As such, the metaphorical utterances of each interviewee have been identified as seeming to be consistent or apparently contradictory. An alternative, critical perspective may try to identify a certain consistency or coherence in what is systematically hidden or neglected as a result of the choice of metaphors.

For example, a number of interviewees spoke of strategy as war or chess and there was a range of metaphors which could be grouped under the broad theme of 'strategy as competition'. One of the ways in which metaphorical meaning works, is that it relies on the speaker's assumption that the listener (audience) shares relevant contextual knowledge, including cultural and background knowledge. Consequently, metaphors carry associated culture-bound inferences as hidden, natural entailments. Given the dominance of 'war metaphors' in published strategy discourse this metaphor is unlikely to have been surprising for the interviewer. However, this commonsense or natural metaphor means that it is unlikely to be explored deeply for its implicit assumptions. Such entailments can act as covert propositions, generating perspectives which implicitly justify particular interpretations and possibly also policy and action (see Bolinger, 1980: 149ff.; Lakoff \& Johnson, 1981: 291, 321; Schon, 1979). For example, one interviewee, working consistently within the metaphorical theme of 'strategy as war against competitors' said that 'management is there to protect the staff from the brunt of the war', and 'management fights off the bull'. What these images evoke for people of a particular cultural background, is images of the valiant and heroic commander, facing danger in the gallant task of protecting and even saving the weak. The hidden or covert propositions include: the non-managerial staff members are weak and defenceless, so they must rely on the management to make the best decisions for them and the business.

From this critical perspective, there may seem to be less of a contrast between images of 'strategy as war' and images of 'strategy as chief executive's dream' or a 'bird's eye-view'. What these images have in common is that they highlight leadership with a focus on the 'big picture' and the external opposition. What is hidden or kept from discussion is the notion of internal processes and relationships within the organizations themselves. The result is that executives can adopt a strategic discourse which seems to cohere with aspects of the new national discourse - a proud new nation engaging with global challenges - whilst perpetuating a discourse of conventional hierarchical relationships which contrasts with the democratic thrust of the national discourse.

Another feature of the initial research is that it tended to lift all the metaphors out of the context of the specific interview questions. Hence the major findings spoke of metaphors of strategy in general. Fairclough's model suggests that a rich feature of analysis would be to analyse the types of strategy metaphors which emerged in relation to each of the specific questions. For example, a key interview question to visit here is 'What is the role of management and staff in strategy?' Looking at responses to this question in relation to strategy discourse elsewhere in the interview may well suggest contradictions or coherence. Focusing on this question could, therefore, give clear signals of the extent to which the respondents see strategy as a component of organizational transformation or conservation of conventional power roles. Fairclough argues that such gaps and contradictions in the discourse can signal how the text works ideologically or may signal social change.

This brief illustration gives a flavour of how the same corpus of interview transcripts may be re-analysed in very different ways to reveal, for example, a much more critical reflection on the assumptions of the discussants about the power relations in their organizations. This has not been the occasion to use this critical perspective to review the findings in detail. Nevertheless, it seems useful to have identified a model of analysis with the different kinds of questions which could have been raised within a more critical framework. These questions could be explored in more detail using this research in a future paper, or applied from the outset in future research of strategy discourse or in metaphor analysis generally.

The discussion also raises some critical issues for critical 
management education. Why, for example, did the researcher not consider, or the supervisor not propose a more critical analytical framework? Or, if such a framework was considered, why was it not adopted? These questions are not intended to detract from what has been very interesting and valuable research. Rather, they point to the need for us, as management educators, to become more critically reflexive practitioners. We need to ask ourselves what features of our management curricula, if any, introduce students to critical perspectives or encourage the use of critical research frameworks.

This is to say that we take seriously the various arguments in French and Grey (1996) for management education to address more than the development of managerial effectiveness. That is, to acknowledge that management education has an educative responsibility to consider the social, political and moral practices of management. As such, our management education curricula need to make a 'reflexive turn' to transcend technical rationality (Roberts, 1996), to reflect critically on management knowledge (Grey, Knights \& Willmott, 1996) and to adopt a democratic programme in which lecturers and staff are encouraged to produce change via teaching and research (Cavanaugh \& Prasad, 1996). Part of this turn would require broadening management education's emphasis on the rational and the individual, to incorporate the equally important aspects of the emotional, the political and the underlying dynamics of groups (Vince, 1996). This is not to ignore the warnings about the limitations, risks and challenges facing such management curricular transformation. It is to argue that we have so much more we need to do if students are to grasp the notion of management as social construction (Collin, 1996) rather than management as external, technical, universal truth (see also Willmott, 1997). Management student research offers a fertile space in which to propagate such a critical management perspective. As this paper has indicated, metaphor analysis and strategy discourse are particularly rich beds through which the seeds of critical research may flower.

In summary, the research sought to understand the importance of metaphor in strategy, and in doing so to understand more about 'strategy' itself and how the teaching and learning of strategy could be best effected. The results were more definitive than anticipated and indicate that innovative approaches to teaching and understanding strategy could usefully be encouraged in order to improve practice in the field.

Ultimately, the heart of strategy may lie in the art of sensemaking and creativity via discourse and conversation. Part of this spoken art lives in and by metaphor, which lightens and eases the paths to new understandings, new directions and to new configurations of individuals, firms and markets.

\section{References}

Aldrich, H. E. 1992. 'Incommensurable paradigms? Vital signs from three perspectives'. In Reed, M. \& Hughes, M. (Eds.). Rethinking organisation: New directions in organisation theory and analysis. London: Sage, pp.16-45.
Alvessen, M. 1993. 'The play of metaphors'. In Hassard, J. \& Parker, M. (Eds.). Postmodernism in organizations. London: Sage, pp.114-131.

Ansoff. I. 1965. Corporate strategy. New York: McGraw Hill.

Ansoff, I, 1991. 'Critique of Henry Mintzberg's 'The Design School: Reconsidering the Basic Premises of Strategic Management',' Strategic Management Journal, 12:449-461.

Argyris, C. 1985. Strategy, change and defensive routine. Boston: Pitman.

Bailey, J. R. \& Ford, C. M. 1994. 'Of methods and metaphors: Theatre and self-expression in the laboratory,' Journal of Applied Behavioural Science, 30:381-396.

Barley, S. R. \& Kunda, G. 1992. 'Design and devotion: Surges of rational and normative ideologies of control in managerial discourse,' Administrative Science Quarterly. 3:363-399.

Barney, J. B. 1994. 'Beyond individual metaphors in understanding how firms behave: A comment on game theory and prospect theory models of firm behaviour'. In Rumelt, R., Schendel, D. \& Teece, D. (Eds.). Fundamental issues in strategy. Harvard: Harvard Business School Press, pp.55-69.

Barry, D. \& Elmes, M. 1997. 'Strategy retold: Towards a narrative view of strategic discourse', Academy of Management Review, 22(2): 429-452.

Baudrillard, J. 1997. 'Aesthetic illusion and virtual reality'. In Zurbrugg, N. (Ed.). Art and artifact. London \& Thousand Oaks: Sage.

Bion W. R. 1961. Experiences in groups and other papers. London: Tavistock Institute.

Black, M. 1962. Models and metaphors: Studies in language and philosophy. Ithaca, NY: Cornell University Press.

Boje, D.M. 2001. Narrative methods for organizational \& communication research. London: Sage.

Bolinger, D. 1980. Language- the loaded weapon. The use and abuse of language today. London \& New York: Longman.

Bourgeois, V. W. \& Pinder, C. C. 1983. 'Contrasting philosophical perspectives in organisational science: A reply to Morgan,' Administrative Science Quarterly, 28: 608-613.

Burgoyne, J. \& Reynolds, M. (Eds.). 1997. Management learning. Integrating perspectives in theory and practice. London: Sage.

Burrell, G. \& Morgan, G. 1979. Sociological paradigms and organisational analysis. Aldershot, England: Gower. 
Carney, T. F. 1990. Collaborative inquiry methodology. Ontario, Canada: University of Windsor.

Cavanaugh, J.M. \& Prasad, A. 1996. 'Critical theory and management education: Some strategies for the critical classroom'. In French, R. \& Grey, C. (Eds.). Rethinking management education. London: Sage, pp.76-93.

Chandler, A. D. Jnr. 1962. Strategy and structure: Chapters in the history of the American industrial enterprise. Cambridge, MA: MIT Press.

Collin, A. 1996. 'The MBA: The potential for students to find their voice in Babel.' In French, R. \& Grey, C. (Eds.). Rethinking management education. London: Sage, pp.132151.

De Cock, C. 1996. High modernity or post modernity? Electronic Journal of Radical Organisation Theory, 2/1. [online] URL http://www mngt.waikato.ac nz/ Research/ejrot/Vol2_1/Exchange/DeCock.asp.

Dictionary.com. 2004. [online] URL:http://dictionary. reference.com/search?q=metaphor\&r=67.

Downing, S. 1992. 'The social construction of strategy: Networking interaction skills amongst business owners'. $\mathrm{PhD}$ thesis Henley Management College/Brunel University.

Downing, S. 1998. 'A narrative analysis of competitive advantage: A case for linking the bottom line to the narrative line.' Paper presented at the $3^{\text {rd }}$ International Conference on Organisational Discourse, King's College, London.

Drucker, P. 1946. The concept of the corporation. New York: The John Day Co.

Drucker, P. F. 1947. Big business: A study of the political Problems of American capitalism, London, Toronto: W. Heinemann.

Easterby-Smith, M., Thorpe, R. \& Lowe, A. 1991. Management research: An introduction. London: Sage.

Eco, U. 1984. Semiotics and the philosophy of language. London: Macmillan Press.

Fairclough, N. \& Hardy, G. 1997. 'Management learning as discourse.' In Burgoyne, J. \& Reynolds, M. (Eds.). Management learning: Integrating perspectives in theory and practice. London: Sage, pp.144-160.

Fairclough, N. 1989. Language and power. London: Longman.

Fairclough, N. 1992a. Critical language awareness. London: Longman.

Fairclough, N. 1992b. Discourse and social change. Cambridge: Polity Press.

Fairclough, N. 1995. Critical discourse analysis. London:
Longman.

French, R. \& Grey, C. 1996. Rethinking management education. London: Sage.

Gentner, D. \& Gentner, D. 1983. 'Flowing water or teeming crowds: Mental models of electricity.' In Gentner, D. \& Stevens, A. L. (Eds.). Mental models. Hillsdale NJ: Lawrence Earlbaum Associates, pp.99-130.

Gergen, K.J. \& Gergen, M. M. 1991. 'Towards reflexive methodologies.' In Steier, F. (Ed.). Research and reflexivity: London: Sage, pp.76-95.

Gouillart, F. 1995. 'The day the music died', Journal of Business Strategy 16(3): 14-20.

Grey, C. \& French, R. 1996. 'Rethinking management education: An introduction.' In French, R. \& Grey, C. Rethinking management education. London: Sage, pp.1-16.

Grey, C., Knights, D. \& Willmott, H. 1996. 'Is a critical pedagogy of management possible?’ In French, R. \& Grey, C. 1996. Rethinking management education. London: Sage, pp.94-110.

Hamel, G. \& Prahalad, C. K. 1995. Competing for the future. Harvard: Harvard Business School Press.

Hampden-Turner, C. 1990. Charting the corporate mind, from dilemma to strategy. Oxford: Blackwell.

Harnad, S. 1982. 'Metaphor and mental duality'. In Simon, T. \& Scholes, R. (Eds.). Language, mind and brain Hilldale, NJ: Erlbaum, pp.189-211.

Hassard, J. 1993. 'Postmodernism and organisational analysis: An overview. In Hassard, J. \& Parker, M. (Eds.). Postmodernism in organizations. London: Sage, pp.1-23.

Hill, R. C. \& Levenhagen, M. 1995. 'Metaphors and mental models: Sensemaking and sense-giving in innovative and entrepreneurial activities', Journal of Management, 21(6): 1057 - 1074.

Hill, S. 1998. 'Metaphor in thought and language.' Term strategy paper, MBA, University of Cape Town.

Holland, J., Holyoak, K., Nisbett, R. \& Thagard, P. 1986. Induction: Processes of inference, learning, and discovery. Cambridge, MA: MIT Press/Bradford Books.

Hunt, S. D. \& Menon, A. 1995, 'Metaphors and competitive advantage: Evaluating the use of metaphors in theories of competitive strategy', Journal of Business Research, 33: 8190.

Jakobson, R. 1960. 'Closing statements: Linguistics and poetics'. In Sebeok, T.A. (Ed.). Style in language. Cambridge: MIT Press, pp.350-71.

Janks, H. 1988. To catch a wake-up: language awareness in the South African context. Unpublished MA dissertation. 
Johannesburg: University of the Witwatersrand

Janks, H. 1996. '1996: Why we still need critical language awareness in South Africa,' SPIL-PLUS, University of Stellenbosch.

Janks, H. 1997. 'An introduction to the work of Norman Fairclough', Newsletter of the South African Applied Linguistics Association, December: 6-9.

Knights, D. \& Morgan, G. 1990. 'Corporate strategy, organizations and subjectivity: A critique'. Organization Studies 12(2): 252-273.

Lakoff, G. \& Johnson, M. 1980. Metaphors we live by. Chicago: University of Chicago Press.

Lakoff, G. 1995. 'Metaphor, morality and politics, or, why conservatives have left liberals in the dust', Social Research, 62(2): 177-213.

Lakoff, G. \& Johnson, M. 1981. 'Conceptual metaphor in everyday language’. In Johnson, M. (Ed.). Philosophical perspectives on metaphor. Minneapolis: University of Minnesota Press, pp.286-325.

Lessem, R, \& Neubauer. 1994. European management systems: Towards unity out of cultural diversity. Maidenhead, Berkshire: McGraw Hill.

Lissack, M. 1997. 'Mind your metaphors: Lessons from complexity,' Long Range Planning, April.

Lissack, M. 1999. 'Complexity: the science, its vocabulary, and its relation to organizations', Emergence, 1(1):110-126.

Lyotard, J-F. 1984. The postmodern condition: A report on knowledge. Manchester University Press.

Markus H. R. \& Kitiyama, S. 1991. 'Culture and the self: Implications for cognition, emotion and motivation', Psychological Review, 98(2): 224 - 253.

Marshak, R. J. 1993. 'Managing the metaphors of change', Organisational Dynamics, 22(1): 44-56.

Martin, J. H. 1990. A computational model of metaphor interpretation. NY: Academic Press.

Miles, M. B., \& Huberman, A. M. 1994. Qualitative data analysis: An expanded sourcebook. 2nd Edition. Thousand Oaks, CA: Sage.

Mintzberg, H. 2004. Managers not MBAs. San Francisco: Berrett-Koehler.

Mintzberg, H., Ahlstrand, B. \& Lampel, J. 1998. Strategy safari: A guided tour through the wilds of strategic management. New York, NY: Free Press.

Mintzberg, H. 1994. The rise and fall of strategic planning. New York: Free Press.
Mintzberg, H. \& Quinn, J. B. 1991. The strategy process: Concepts, contexts, cases. 2nd Edition. Englewood Cliffs, NJ, Prentice Hall.

Mintzberg H. 1987. 'The strategy concept ll: Five Ps for strategy', California Management Review, Fall: 25-31.

Morgan, G. 1983. 'More on metaphor: Why we cannot control tropes in administrative science', Administrative Science Quarterly, 25: 601-607.

Morgan, G. 1986. Images of organisation. Beverley Hills, CA: Sage.

Nonaka, I. 1991. 'The knowledge-creating organisation', Harvard Business Review, Nov-Dec: 96-104.

Nonaka, I. 1994. 'A dynamic theory of organizational knowledge creation', Organization Science, 5(1): 14-37.

Palmer, I. \& Dunford, R. 1996. 'Conflicting uses of metaphor: Reconceptualising their use in the field of organisational change', Academy of Management Review, 21(3): 691-717.

Pascale, R.T. 1990. Managing on the edge: How successful companies use conflict to stay ahead. London: Viking.

Pascale, R. 1989. 'The paradox of corporate culture: Reconciling ourselves to socialisation'. In Tushman, M.L., O'Reilly, C. \& Nadler, D.A. (Eds.). The management of organisations: Strategies, tactics and analyses. New York: Harper and Row.

Pepper, S.C. 1942. World hypotheses. Los Angeles, University of California Press.

Porter, M. 1995. 'Towards a dynamic theory of strategy'. In Rumelt, R., Schendel, D. \& Teece, D. (Eds.). Fundamental issues in strategy. Harvard: Harvard Business School Press, pp.423-460.

Porter, M. 1996. 'What is strategy?' Harvard Business Review, 74(6):61.

Prahalad, C. K. \& Bettis, P. 1986. 'The dominant logic', Strategic Management Journal, 7: 485-501.

Putnam, L., Phillips, N. \& Chapman, P. 1996. 'Metaphors of communication and organisation', In Clegg, S. R., Hardy, C. \& Nord, W.R. (Eds.). Handbook of organisation studies. London: Sage.

Reynolds, M. 1997, 'Towards a critical management pedagogy', In Burgoyne, J, Reynolds, M. (Eds.). Management learning: Integrating perspectives in theory and practice. London Sage: pp.312-328.

Richards, I. A. 1936. The philosophy of rhetoric. NY: Oxford University Press.

Ritzer, G. 1993. The McDonaldization of society. Thousand Oaks, CA: Pine Forge Press. 
Roberts, C. 1996. 'Information structure in discourse: Towards an integrated formal theory of pragmatics'. In Yoon, J. H. \& A. Kathol, (Eds.). OSU Working Papers in Linguistics, 49, Ohio State University.

Sanchez, R. 1997. 'Strategic management at the point of inflection: Systems, complexity and competence theory', Long Range Planning, 30(6): 939 - 946.

Saussure, F. de. 1959. A course in general linguistics. New York Philosophical Library.

Schon, D.A. 1979. 'Generative metaphor: A perspective on problem-setting in social theory.' In Ortony, A. (Ed.). Metaphor and thought. Cambridge: Cambridge University Press, 254-283.

Shrivastava, P. 1986. 'Is strategic management ideological?’, Journal of Management, 12(3): 79-92.

Sinclair, J. 1994. 'Reacting to what?', Journal of Organisational Change Management, 7(5): 32-40.

Stacey, R. D. 1996. Complexity and creativity in organisations. San Francisco: Berret-Koehler.

Stacey, R. D. 2002. 'Organisations as complex responsive processes of relating', Journal of Innovative Management, 8(2): 27-39.

Stone, E. F. 1978. Research methods in organizational behavior. Glenview, IL: Scott, Foresman \& Company.

Taylor, W. 1984. 'Metaphors of educational discourse'. In Taylor, W. (Ed.). Metaphors of education. London, Heinemann, pp.4-20.

Tinker, T. 1986. 'Metaphor or reification: Are radical humanists really libertarian anarchists?', Journal of Management Studies, 23: 363-384. Quoted in Palmer, I. \& Dunford, R. 1996. 'Conflicting uses of metaphor: Reconceptualising their use in the field of organisational change', Academy of Management Review, 21(3): 691-717.

Tsoukas, H. 1992. 'Postmodernism, reflexive rationalism and organisational studies: A reply to Martin Parker', Organisation Studies, 13: 643-649. Quoted in Palmer, I. \& Dunford, R. 1996. 'Conflicting uses of metaphor: Reconceptualising their use in the field of organisational change', Academy of Management Review, 21(3): 691 717.

Veale, R. A. 1995. 'Metaphor comprehension Home Page', University of Dublin. [online] URL: http://www. compapp.dcu.ie/ tonyv/ .

Veale, T. \& Keane, M. 1994. 'Belief modelling, intentionality and perlocution in metaphor comprehension'. In Proceedings of the Sixteenth Annual Meeting of the Cognitive Science Society, Atlanta, Georgia. Hillsdale, NJ: Lawrence Erlbaum.
Vince, R. 1996, Managing change: Reflections on equality and management learning. Bristol: The Policy Press.

Vygotsky, L.S. 1962. Thought and language. Cambridge, MA: MIT Press. (Original work published 1934).

Vygotsky, L.S. 1978. Mind in society: The development of higher psychological processes. Cambridge, MA: Harvard University Press.

Webster's online dictionary. [online] URL: http:// www.webster-dictionary.org/definition/metaphor . Accessed 11 Nov 2004.

Weick, K. 1994. Cartographic myths in organizations. In Tsoukas, H. (Ed.). New thinking in organizational behaviour. London: Butterworth-Heinemann.

Whittington, R. 1993. What is strategy: And does it matter? London: Routledge.

Williams, T. W. 1994. 'The end of strategy', Futures, 26(4): 365-377.

Willmott, H. 1997. 'Critical management learning'. In Burgoyne, J. \& Reynolds, M. (Eds.). Management learning: Integrating perspectives in theory and practice. London: Sage, pp.161-176. 